\title{
Wykładniki określoności / nieokreśloności a pewien typ wyrażeń ekspresywnych w języku bułgarskim i polskim
}

1. Modelowanie na poziomie semantycznym kategorii określoności / nieokreśloności zaowocowało w polskiej literaturze językoznawczej fundamentalnymi pracami, opartymi na teorii referencyjnej lub kwantyfikacyjnej (por. Topolińska 1981; Косеска-Тошева, Гаргов 1990; Karolak 2001). Opracowania te pozwoliły ukazać całą złożoność tej problematyki nie tylko w odniesieniu do kształtu modelu, na poziomie semantycznym, ale także do znaków językowych realizujących na poziomie powierzchniowym, w strukturze zdaniowej poszczególne podkategorie tej kategorii semantycznej. Trudność problemu wiąże się także $\mathrm{z}$ tym, że w systemach językowych formalizacja kategorii określoności / nieokreśloności może mieć szerszy lub węższy zakres, oraz z tym, że w takich językach jak polszczyzna w ogóle nie doszło do jej zmorfologizowania: realizowana jest wyłącznie przez elementy leksykalne (np. zaimki) lub brak znaku („zero”) o funkcji czytelnej zazwyczaj w szerszym kontekście.

Zakres semantycznej kategorii określoności / nieokreśloności jest w pracach zakreślany różnie: obejmuje funkcje fraz odnoszących się do obiektów przedmiotowych (głównie w ujęciach referencyjnych) lub poszerzony jest na frazę werbalną (w ujęciu kwantyfikacyjnym - por. Косеска-Тошева, Гаргов 1990). Wśród wielości problemów opisu szczególnie trudne jest odniesienie się do fraz 
stanowiących efekt procesów nominalizacyjnych - fraz, których centrum tworzy nотеп abstractum, np. арестуване - арестуване на един войник; арестуването на Левски itp. Analiza cech semantycznych takich fraz, przeprowadzona przez Stanisława Karolaka, stanowi propozycję ich kategoryzacji na podstawie przyjętego przez autora modelu dla kategorii określoności / nieokreśloności. Punktem wyjścia tej kategoryzacji jest tzw. stopień zamknięcia propozycji w powiązaniu z zupełnością / niezupełnością intensjonalną (por. Karolak 2001, 317-319). O stopniu zamkniętości propozycji decyduje to, w jakim zakresie pozycje otwierane przez pojęcie są wypełnione i jaki jest charakter tego wypełnienia. To kryterium pozwala na wyodrębnienie propozycji zamkniętych (z wypełnionymi wszystkimi pozycjami przez stałe pojęciowe), niedomkniętych (w których część pozycji pozostaje pusta) oraz otwartych (wszystkie otwierane pozycje pozostają puste). Na tej podstawie autor uściśla zakres sfery nieokreśloności / określoności: do nieokreśloności należą pozycje otwarte w propozycji i pozycje wypełnione pojęciami intensjonalnie niezupełnymi, do określoności - pozycje wypełnione pojęciami intensjonalnie zupełnymi oraz niedomknięte lub zawierające pozycje puste, których wartości są jednoznaczne (por. Karolak 2001, 317-319). Przyjęte kryteria pozwalają na ustalenia dotyczące klasyfikacji fraz typu On a promis un mariage - une promesse de mariage, a także Un piéton a été renversé - le renversement d'un piéton: obie frazy reprezentują propozycje niedomknięte i realizują nieokreśloność, podobnie jak fraza la mort d'un enfant - Un enfant est mort nie wyraża określoności zdarzenia - „nie może ono być określone, ponieważ nieokreślony jest przedmiot w nim uczestniczący. Rodzajnik określony jest tu znakiem jedyności zdarzenia dla danego przedmiotu" (por. Karolak 2001, 318-319).

2. Uwzględnienie przytoczonych ustaleń teoretycznych stanowi podstawę analizy przedstawianego $\mathrm{w}$ tym artykule materiału $\mathrm{z}$ języka bułgarskiego, który w części przykładów nasuwa pewne problemy interpretacji funkcji występujących wykładników określoności / nieokreśloności.

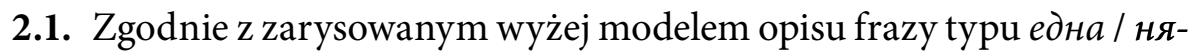
каква история // една / някаква случка w przykładzie 1) realizują nieokreśloność, mogą też zawierać zaimki nieokreślone нещо, някакъв, także brak wykładnika dopuszczający interpretację przez нещ, някакъв, por.:

(1) Той ми разказа една история / една случка. // Той им разказа някаква история.

Por. też: Той изтърси една история. // Цяла вечер той дрънкаще едни (интересни) истории. // Един приятел под влияние на алкохола из- 
Wykładniki określoności / nieokreśloności a pewien typ wyrażeń ekspresywnych... 135

търси една мъдрост. // Илия дрънкаше нещо. // И го обзема страх да не изтьрси някоя глупост. // Той от време на време ми дрънкаше приказки (= някякви / едни приказки).

Niedomkniętość propozycji i problem, czy puste pozycje mają wartość, którą można określić w sposób jednoznaczny (wówczas należałyby do sfery określoności), ilustrują zdania typu (2):

(2) Петко редовно дрънка за журналистика. // Тя дрънка нещо за извънземните.

W istocie wykładniki typu история są informacyjnie bliskie takim wyrażeniom, jak нещо, случай - mogą ewentualnie wskazywać na zdarzeniowość, nieraz dodatkowo mogą zawierać ocenę przekazywanej treści, por. Toŭ ни каза една мъдрост. = Той ни каза нещ,о, което е мъдро. itр.

2.2. Wystąpienie zaimka anaforycznego może odsyłać do propozycji, których pozycje argumentowe są określone jednoznacznie lub są nieokreślone, por. (3) i (4):

(3) Петьр прочете за смъртта на Папата и ми разказа (за) това / тази история // и ми го разказа.

(4) Тази случка с кучето, Пешо и неговите приятели е много известна и Данчо много пъти ми я разказваше.

(5) Петър прочете за смъртта на един полски офицер и ми разказа за това // и ми го разказа.

Podobnie uzależnione od kontekstu (niejednokrotnie dalekiego, włącznie $\mathrm{z}$ odwołaniem się do pamięci odbiorcy) są interpretacje $\mathrm{w}$ dalszych przykładach, por.:

Тази история е известна и Никола много пъти я е разказвал. // Тъй де, какви ги дрънкаш! // Такива неща мога да ги дрғнкам до утре. // Аз отдавна го дрънкам. // Спомни си какви ги дрънкаше Р.О. когато без време преподписа договора за газа с руснаиите...

2.3. Szczególnym przypadkiem są idiomatyczne wypowiedzenia, w któ-

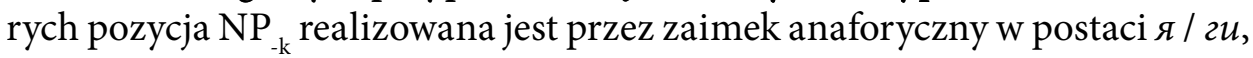
które może być rekonstruowane jako paбота / история // работи / истоpuu (przy czym leksemy te nie występują w kontekście) i stanowić implikaturę - odsyłacz do sytuacji, por.:

Свъриихме я! = Свършихме тази работа! [...] = Свъриихме това! / Свъриихме го!

I w tym wypadku anafora może, ale nie musi (w myśl stosowanego tu modelu opisu) łączyć się z określonością i zamkniętością / niedomkniętością propozycji. 
Por. też: Само ми кажи къде в България може да се намери такова куче и повече не ми се меси. Аз ще я нареждам по-нататьк. (= аз ще нареждам това по-нататък).

И ти да не ми кажеш досега / Из иелия град ги разнасяш, а на мене нищзо.

Tego typu struktury ulegają sfrazeologizowaniu, por. np.:

- закъсвам / закъсам я / го 'изпадам в затруднено, тежко положение': Oт пет изпита можах да взема само един. Закъсах я! (РБЕ 5, 399);

- свърших я 'попаданах в тежко, неблагоприятно положение; загазих' (FR II, 281).

Por. też:

- свърши се тя / тая / оная 'за нещо, което няма да се върне, възстанови, което е безвъзвратно загубено': Не чуваш ти какво четат хората между редовете на вестнииите: братушките стигнали до Румғния. Свърши се вече тя. Беше, каквото беше! (FR II, 281);

- тьнко я преда (диал.) 'усложнявам нещо, като не казвам направо, усуквам': Виждам, че ти е дошъл най-сетне умът, но пак тънко я предеш. (FR II, 425);

- усуквам я / го // опявам го (по килфарски неодобр.) 'не казвам истината направо; извъртвам': - Ако трябва да чакаме някого, направо кажи, не го усуквай! // - Ние средняиите не пьдим! - Пғдете ги, щом така действувате! Пътят е ясен от устава бе, какво ще я усуквате! (FR II, 456).

Anaforyczna fraza typu моята работа w analogicznej do omawianej tu funkcji w zwrotach frazeologicznych może być zredukowana do zaimka realizującego kategorię osoby gramatycznej - моята, твоята, por. np.:

- свърии се моята / вашата 'загубвам безвъзвратно всичко (сили, влияние, власт и под.): Още ли не си разбрал, че твоята се свгрии? Щом жена ти те бие, и аз ще те набия (FR II, 280).

Tego typu sfrazeologizowane wyrażenia mają jeszcze inne warianty, por. np.:

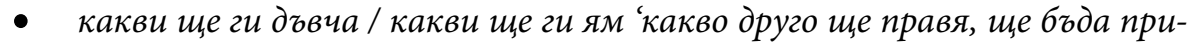
нуден да постьпя по един или друг начин; нямам изход”: "Дали щял да ги купуванконсуматорвт, или не”... Смешки! Ще ги купува като поп. И ти ще ги купуваш. Какви ще ги дъвчеш. Щом не можеш без тях! (FR I, 466).

2.4. Anaforyczne frazy typu maзи история / тази случка mogą występować w strukturach zdaniowych jako komponent tzw. podwojonego dopełnienia, por. np.: 
Wykładniki określoności / nieokreśloności a pewien typ wyrażeń ekspresywnych... 137

Петър ми я разказа тази история. / Тази история Петьр ми я разказа сноши.

W strukturach tego typu dopełnienie pełni funkcję tematyczną, z czym wiąże się ich funkcjonalna określoność (por. Guentchéva-Desclés 1994). Por. np. (6):

(6) Книгата я купих вчера. // Тя го е получила кучето като подарък.

W zdaniach typu (6) akcent nie może więc padać na frazę dopełnieniową, lecz na inny komponent zdania o funkcji rematycznej (np. na orzeczenie, okolicznik itp.) - w przykładach cytowanych w (6) są to np. frazy вчepa I като подарък lub купuх. Nie są też oczywiście możliwe zdania z podwojonym dopełnieniem i charakterystyczną dla nich intonacją (akcentem zdaniowym na frazie dopełnieniowej) typu (7) i (8):

(7) ${ }^{\star}$ Една книга я купих вчера. // *Тя го е получила едно куче като подарък.

(8) ${ }^{\star}$ Той ми я разказа една история.

W kontekście wyżej przytoczonych przykładów fraz o funkcji anaforycznej, zredukowanych do elementu zaimkowego, nie zaskakują sfrazeologizowane zwroty typu:

- не ми ги продавай тия / тези // на кого (кому) ги продаваш тия 'не се опитвай да ме лъжеш и заблуждаваш, мене не можеш да изльжеш, не ти вярвам': Подвеждаш властта и другарите,..., че си лежал в затвора като политически ... Кому ги продаваш тия? (FR I, 698);

- другимуги продавай тия (/ тези) 'j.w.': Ти другимуги продавай тези, че работиш само за идеята и за нищо друго не мислиш (FR I, 279);

- тя моята е дълга // тя моята край няма 'за тежки, неприятни, мбчителни преживявания, които са продължили дълго време': - А вие кой бяхте? - Ех, тя моята край няма. // Вельо ме казват, Вельо Киров от Главан. Тя е дълга мойта, ама аз накъсо ще разправя (FR II, 429);

- тя моята се е видяла 2. 'Ясно ми е, че за мене няма никаква надежда за по-добро бъдеще, че нищо хубаво не ме очаква”: И приказките им знае Рале, и с тях [пеперудите] се е радвал на ношта и на месеиа, когато сам имаше в сърие радост ... Пък сега? - Тя се е видяла мойта (FR II, 429).

W ostatnich dwu frazeologizmach możliwe jest wypełnienie centrum frazy za pomocą leksemu autosemantycznego - cъдб ${ }^{1}$.

${ }^{1}$ Por. też przykłady braku wypełnienia centrum frazy przez nomen, które jednoznacznie jest odtwarzane: Като ти светна един! = Като ти светна един шамар! // Той не беше с всичкия си. = Той не беше с всичкия си ум. // Мятам / Хвърлям му му една. = Мятам / Хвърлям му му една чаша (por. polskie: Pójdziemy na jednego = Pójdziemy na jeden kieliszek). 
2.5. Na tle zanalizowanych wyżej cech struktur zdaniowych zwracają uwagę wypowiedzenia typu:

(9) Той дойде вчера и ми я изтьрси една...

Oczywiście zdanie to nie reprezentuje struktury typu (7) i (8) (z omówionymi cechami akcentu zdaniowego), które, jak wskazano, są niegramatyczne. W tym wypadku akcent pada na frazę eднa, a więc ta właśnie fraza jest rematyczna.

Takie struktury zdaniowe mają pewne cechy charakterystyczne:

- intonacja nie reprezentuje typu charakterystycznego dla neutralnej intonacji zdaniowej; należy ją zaliczyć do typu wypowiedzeń niedokończonych - brak typowej dla bułgarskiego zdania oznajmującego kadencji lekko opadającej (por. Савицка, Бояджиев 1988); odznacza się przedłużeniem tonu końcowego (co oddaje wielokropek) i pewną emfazą akcentuacyjną na końcowym един / една / едни; brak pauzy przed един / една / eднu, która by tę frazę wyodrębniała;

- brak wypełnionego centrum frazy realizującej argument propozycjonalny (np. uстория, paбота) - obecny jest tylko wykładnik nieokreśloności, który jest obligatoryjny, podobnie jak krótka forma zaimkowa w pozycji dopełnieniowej, por. niegramatyczne (przy wskazanej wyżej intonacji):

*Той я изтърси ... / *Той изтърси една...

Por. dalsze przykłady:

- Той дойде и (ияля вечер) ги дргнкаме едни ... няма да ти разказвам какви.

- Той я изтьрси една...

- Той ги върии / прави едни...

- Итиги говории едни...

- Аз муя изтгрсих една...

- Аз муги дргнках едни...

Parafrazy tego typu wypowiedzeń zawierają elementy, które wskazują na ekspresję (najczęściej są nacechowane pejoratywnie bądź podkreślają zaskoczenie - niemiłe - nadawcy). Niepełna informacyjnie fraza, reprezentowana przez една, едни mоże więc być substytuowana przez np. лоша / страшна / мрғсна / скандална / работа; глупости; невероятни неща itp., a wyrażenia mają charakter frazeologizmów ograniczonych strukturalnie i dystrybucyjnie (ze względu na zasób występujących leksemów ewentualnych kontekstów poszerzających wypowiedzenie), por. np.:

Той ми я изтьрси една... = Той ми изтьрси (разказа) една мрғсна / скандална / невероятна история. // Той ми изтьрси (разказа) една история, не мога да ти опиша. 
Wykładniki określoności / nieokreśloności a pewien typ wyrażeń ekspresywnych... 139

И ти ги говориш едни... 'глупости говориш'

Свъриил я е една... (като кучето на нивата) 'Лоши неща е направил'

2.6. Ekspresywność wypowiedzeń typu Той ми я изтърси една... przejawia się więc przez specyficzne cechy formalne (bez względu na występowanie w niektórych z tych wypowiedzeń wyrazów nacechowanych ekspresywnie). Jest to operowanie wykładnikami w postaci zaimków w funkcji anafory i wykładnikiem nieokreśloności przy braku wypełnienia centrum frazy przez nomen. Wykorzystany jest także środek suprasegmentalny w formie intonacji zdaniowej. Interpretacji wymaga funkcja zaimków anaforycznych i wykładników един / една / едни. Wydaje się, że zaimki mają funkcję odsyłacza do implikatury - nadawca „wie”, o czym był informowany, jaki fakt miał miejsce. Odbiorca może, ale nie musi znać tych faktów, może to być także sygnał kataforyczny - nadawca w dalszej części komunikatu może uściślić informacje brakujące odbiorcy. Interpretacja wykładników един / една / едни jest pewnym problemem. Mimo braku pauzy oddzielającej je od reszty struktury można sądzić, że stanowią sygnał predykacji dodanej (realizację jej części), którą odtwarzałyby zdania typu това са лоши / невероятни истории / неща itp. Odbiorca uzyskuje więc przekaz zawierający informację o ocenie faktu przez nadawcę. Komponent oceniający sygnalizowany jest w omawianych zwrotach frazeologicznych przez typ struktury, natomiast istotne jest to, że fraza една история / едно нещо // едни истории / неща jest pochodną (jak wynika to z parafrazy) pozycji predykatywnej, co uzasadnia wystąpienie wykładników nieokreśloności ${ }^{2}$. Można też tu przytoczyć wyrażenia o takim właśnie kształcie, zawierające nadwyżkę ekspresywną: Ама и аз съм една... // И той е един... Mają one odpowiedniki bardziej neutralne: Ама и аз съм една глупачка. И той е един чешит.

3. Warto przyjrzeć się odpowiednikom analizowanych wyrażeń typu (9) w języku polskim. Nie jest w nim możliwe stworzenie analogicznej struktury formalnej, por.:

(10) *Piotr siedział u nas caly wieczór $i$ je opowiadał jedne...

Możliwe są natomiast struktury zawierające frazy niepełne (przy braku nomen - centrum frazy w postaci np. historia / rzecz) typu jedne takie (ale nie: jedne lub takie), por.:

${ }^{2}$ Co do różnicy funkcjonalnej między wykładnikami bułg. eдuн - някакъв - wykładnik zerowy i funkcji pol. jeden, pewien por. Ka rolak 2001. 
(11) ${ }^{\star P i o t r ~ s i e d z i a ł ~ u ~ n a s ~ c a ł y ~ w i e c z o ́ r ~ i ~ o p o w i a d a ł ~ j e d n e . . . ~ / / ~}{ }^{\star P i o t r ~ s i e d z i a ł ~}$ u nas cały wieczór i opowiadał takie...

(12) Piotr siedział u nas cały wieczór i opowiadał jedne takie...

- lepiej jednak:

(12) a. Piotr siedział u nas cały wieczór i opowiadal jedne takie historie / takie historie...

Wydaje się także, że interpretacja typów (12) / (12a) nie zawiera jednoznacznego komponentu pejoratywnego, odniesionego do faktu, który sygnalizuje fraza dopełnieniowa.

Podsumowując: analizowane w artykule bułgarskie wypowiedzenia typu Той ги върии / прави едни... / Аз му ги дрънках едни... są przykładem zastosowania wykładników określoności (także w funkcji anaforycznej) / nieokreśloności w strukturze nacechowanej ekspresywnie. Ten naddatek semantyczny jest osiągany przez zastosowanie niepełnej strukturalnie frazy (една / еднu), nietypowo występującego zaimka w funkcji dopełnienia (możliwa jest jego funkcja kataforyczna ${ }^{3}$ ) i przez specyficzną intonację. Interpretowanie zastosowanej struktury formalnej jako struktury, która stoi w sprzeczności z cechami zdań z podwojonym dopełnieniem, jest złudne - świadczy o tym inna niż w tych ostatnich strukturach strukturalizacja tematyczno-rematyczna i funkcje fraz.

\section{Literatura}

Guentchéva-Desclés Z., 1994, Thématisation de l'object en bulgare, Paris.

Ka rolak S., 2001, O pojęciach określoności i nieokreśloności, [w:] S. Ka rolak, Od semantyki do gramatyki. Wybór rozpraw, Warszawa, s. 315-335.

Косеска-Тошева В., Гаргов Г., 1990, Българско-полска съпшоставителна граматика, t. II: Семантичната категория определеност/неопределеност, София.

Савицка И., Бояджиев Т., 1988, Българско-полска съпоставителна граматика, t. I: Фонетика и фонология, София.

Topolińska Z., 1981, Remarks on the Slavic Noun Phrase, Wrocław.

Ekscerpowane źródła

RBE - Речник на българския език, т. 5, София 1987.

FR - Фразелогичен речник на българския език, t. I-II, София 1974-1975.

Dane $\mathrm{z}$ kwerendy internetowej.

${ }^{3}$ Por. np. odesłanie do elementu znanego nadawcy i odbiorcy: Какви ги разказваш! = Какви са тези истории, които разказваш! 


\title{
The Semantic Variants of Verbs in a Semantic- -syntactic Description and Lexicographic Practice (on the Basis of Bulgarian Language)
}

\author{
(Summary)
}

The problem of establishing the criteria separating homonymic lexical units and their semantic variants is crucial in lexicographic description. The paper illustrates the basis of a semantic-syntactic description of verbs in which the separation of predictave units having the same semantic features is relevant. Confronting the semantic-syntactic approaches with the Bulgarian lexicographic practice allows showing their similarities and differences; it is also pointed out that lexicographic approaches based on the intuition of native speakers lead to certain inconsistencies. 